Revue Française de Civilisation Britannique

\title{
Margaret Thatcher in Spitting Image
}

Margaret Thatcher dans Spitting Image

Yves Golder

\section{(2) OpenEdition}

1 Journals

Electronic version

URL: http://journals.openedition.org/rfcb/4891

DOI: $10.4000 /$ rfcb.4891

ISSN: 2429-4373

Publisher

CRECIB - Centre de recherche et d'études en civilisation britannique

\section{Electronic reference}

Yves Golder, «Margaret Thatcher in Spitting Image », Revue Française de Civilisation Britannique [Online], XXIV-4 | 2019, Online since 25 November 2019, connection on 27 November 2019. URL : http:// journals.openedition.org/rfcb/4891; DOI : 10.4000/rfcb.4891

This text was automatically generated on 27 November 2019.

\section{(c) $($ ) $\odot$ (8Y NO}

Revue française de civilisation britannique est mis à disposition selon les termes de la licence Creative Commons Attribution - Pas d'Utilisation Commerciale - Pas de Modification 4.0 International. 


\title{
Margaret Thatcher in Spitting Image
}

\author{
Margaret Thatcher dans Spitting Image
}

\section{Yves Golder}

\section{Introduction}

1 The political dimension of British caricatures developed in the eighteenth and nineteenth centuries when caricaturists like William Hogarth and James Gillray portrayed politicians and the society of their time with a satirical outlook. When, in the eighteenth century, the word "caricature" made its appearance in Great Britain, it referred to engravings having a comical or satirical purpose. ${ }^{1}$ That said, before it even reached Great Britain, this form of graphic satire had emerged both in Italy with baroque caricature and in Germany with symbolic engravings dating from the time of the Protestant Reformation. ${ }^{2}$ Moreover, we can note that caricature is endowed with a formidable capacity of adaptation. It was already present in theatre during the Greek Antiquity when actors wore masks called persona to represent specific people, attitudes or emotions.

2 In Spitting Image, the use of puppets allowed for a caricature which could be broadcast on television. In the 1980s, television was developing at full pace as most Western European households could get an access to this medium. Moreover, the appearance of satellite television made for a better broadcasting quality. When the ITV network was launched in 1954, its main objective was to compete with the BBC and to count on its advertising revenue in order to finance its programmes. It was therefore based on a much more liberal approach than the $\mathrm{BBC}$ right from its creation.

3 Spitting Image was created by Martin Lambie-Nairn, Peter Fluck and Roger Law. It was first broadcast in 1984 but its production had to stop in 1996 because of a continuous decline in viewership all along the 1990s. That said, by the end of the 1980s, its viewership peaked at around fifteen million people. ${ }^{3}$ The first nine out of the eighteen seasons that the series counts were made while Margaret Thatcher was in power as Prime Minister, that is to say from 1984 to 1990. It seems that as Margaret Thatcher's political image ${ }^{4}$ was full of paradoxes and contradictions, it was possible to elaborate a 
complex caricature out of it. Besides being a specialist of the British political system, Jacques Leruez published several books on Margaret Thatcher. In one of these works, he wrote that she was "the most important Prime Minister since Churchill and Attlee"5 and that she was not only a person like everyone else but became a "character" ${ }^{\prime}$ as if she were the hero of a fictional story. Biographer Janet Fallon also noted that she was a " remarkable leader" because she revolutionised British politics. During her premiership, she was often considered as an icon or myth, and she probably became even more of a mythical figure after her resignation in 1990.

4 The name of the show, Spitting Image, implies that the puppets faithfully mirror the different celebrities represented. Of course, the main feature of any caricature is that it is a distortion of reality. ${ }^{8}$ Therefore, the aim may have been to show the hidden faces of those celebrities and what they generally do not disclose in front of TV cameras. Politicians are indeed often presented as experts in the art of dissimulation because, with the help of their media advisers and spin doctors, ${ }^{9}$ they want to give a positive image of themselves. Beyond constituting an entertainment, did Spitting Image succeed in unveiling the most negative aspects of Margaret Thatcher and in building an efficient criticism by, for example, making fun of her? As Brian McNair remarks, any media organisation plays two complementary roles : conveying the politicians' message and providing a journalistic bias. ${ }^{10}$ In this respect, Spitting Image necessarily built its parodies on real elements and, in spite of the self-censorship of the BBC and ITV on issues such as the Falklands War or the IRA attacks, ${ }^{11}$ it managed to portray the British political stage with a new, irreverent approach.

5 In this article, the different ways in which Margaret Thatcher was caricatured and ridiculed in the TV show will be contrasted with what she wanted to display in front of her fellow citizens. The main purpose will be to emphasize the most relevant and interesting extracts which were selected on two main criteria : they had to correspond to different periods of Margaret Thatcher's time in power and to represent various aspects of her political image. Among the nine seasons featuring Margaret Thatcher as Prime Minister, particular attention was paid to the very first episodes through which she became an essential character of the show. The four parts of this study which emerged from this selection of representations and broadcasts cover such matters as her unpopularity, authoritarianism, her negative image as a sadistic woman and the ambiguities concerning her sex. I would like to encourage the readers to watch the video extracts indicated in the footnotes which are freely available on YouTube.

\section{From political outsider ${ }^{12}$ to unpopular leader}

6 Margaret Thatcher was born in Grantham, a small town in Lincolnshire. Her parents, Alfred and Beatrice Roberts, were the owners of a grocery shop where the young Margaret Roberts was helping when she was not at school, at her piano lessons or at the local Methodist church to attend the Sunday's services. ${ }^{13}$ From the very beginning of her lifetime, she thus grew up in an environment which was quite different from that of other children of her age. When she became a public figure, she often referred to the values given to her by her parents and, among others, mentioned thrift, hard work, personal responsibility and determination. Her battle to get elected as Leader of the Conservative Party in 1975 was fought with a clear message : she was different from most male Conservative politicians who had grown up in aristocratic families and could 
therefore not share the same values as theirs. In her autobiography, she made the following statement :

I was conscious of being the first research scientist to become Prime Minister almost as conscious, in fact, as I was of being the first woman Prime Minister. ${ }^{14}$

7 In Spitting Image, her values are turned into derision. For example, the "Grantham anthem" 15 sung by Margaret Thatcher's media person ${ }^{16}$ puts forward the doublemeaning of the word "value" as the lyrics of the song consist in an enumeration of products and their respective cost. This representation reflects Margaret Thatcher's childhood as a "grocer's daughter" ${ }^{17}$ who belonged to the middle class. Her puppet is shown playing the piano on a till while the sound of an organ can be heard, thus highlighting her religious devotion. The conflation of religion and money creates a disturbing atmosphere showing that the Prime Minister's values are only materialistic and that they lack real substance. At the end of the performance, Margaret Thatcher's puppet declares that she has "made the universe". This assertion denounces the Prime Minister's determination to make her fellow citizens share the same values as hers. We may therefore claim that Spitting Image provides a representation of Margaret Thatcher as an authoritarian God, comparable to that of the Old Testament. After all, when she became Prime Minister in 1979, her first words were a prayer from Saint Francis of Assisi. In Spitting Image, according to this religious representation, she thought she was endowed to destroy everything that was not part of her "universe", just like she wants to get rid of Scotland, which she considers as a "testing ground" in another episode. ${ }^{18}$

8 Another particularity which made Margaret Thatcher an unusual politician was her womanhood. In Spitting Image, the mixture of her politician and housewife images is something which is quite often satirised. For example, her puppet is shown wearing an apron covered with blood, and cutting meat in her Cabinet meeting room while talking about the elections. ${ }^{19}$ This representation thus reflects her own use of her femininity to appeal to female voters and relies on the stereotypes of femininity and masculinity which often depend on the conflicting notions of softness and toughness. This tough woman image appears in the closing credits of another episode where we can hear Margaret Thatcher insulting her colleagues at the House of Commons. ${ }^{20}$ Her use of obscene language highlights the discrepancy between her and other members of the Conservative Party who, at that time, were often part of the aristocracy and showed an image of decency and politeness.

9 Her specificity as a political outsider could either be an asset or a disadvantage for Margaret Thatcher. Spitting Image used it as a disadvantage to show her unpopularity. In the series, she is often presented as an austere politician that British people hated even though, in real life, she had many supporters who allowed her to remain in power for eleven years. When the puppet representing Gordon Reece, her media adviser, tries to modify her image and self-presentation, nothing really suits her and he must admit that all the modifications undergone by the Prime Minister haven't really helped her boost her popularity. ${ }^{21}$ Moreover, in another extract, when Margaret Thatcher's media persona asks her hairdresser to make her look "universally popular", he just takes his razor's blade and cuts her head. ${ }^{22}$

10 Besides, her differences with other politicians and her lack of experience in certain areas caused many questionings and criticisms concerning her legitimacy. In Spitting Image, her puppet sings My Way while, in the background, pictures of the most negative events which took place during her mandates are shown. ${ }^{23}$ For example, we can see the 
Falklands War ${ }^{24}$ with the sinking of the Belgrano, police repression during massive antiThatcher demonstrations or the bombings in Libya. ${ }^{25}$ Margaret Thatcher thus seems to be proud of her very personal accomplishments whereas we are incited to consider only the worst of what took place during her premiership. In that extract, she is presented as an extremely self-confident world leader who thought that she could never be overthrown. As we shall see it now, this caricature was recurrent in Spitting Image.

\section{From supreme leader to would-be dictator}

In several episodes, Margaret Thatcher's media persona appears disguised as Queen Elizabeth II. For that purpose, she often wears a crown and royal garments. ${ }^{26}$ The Prime Minister's desire to embody the monarch reveals her unstoppable and boundless ambition. Of course, it was profitable for the media to create some form of rivalry between the two women. Moreover, one of Margaret Thatcher's main characteristics was her fervent patriotism, especially exhibited after the British victory in the Falklands in 1982. Caricaturists like Nicholas Garland ${ }^{27}$ said that her victory at war made her an iconic personality who then became omnipresent in the media. ${ }^{28}$ It is also possible that the real Margaret Thatcher wanted to become an allegory of the nation, like Britannia or the Queen.

In the very first episode of the TV show, the opening scene shows Margaret Thatcher's entry with the royal ornaments after she is announced to her ministers as their "most graceful sovereign, the Queen". ${ }^{29}$ This first instalment of the whole series set the tone for the ones to follow and announced an omnipresent as well as omnipotent Margaret Thatcher. The lack of charisma of Michael Foot, ${ }^{30}$ contributed to her attractivity as a main character in the show but we may argue that it was also because her character had such a comic potential that it became essential to the series. Indeed, some personal attributes like her behaviour, voice and intonations could easily be parodied.

Margaret Thatcher's puppet encounters other world leaders to whom the British Prime Minister tries to show the extent of her power. For example, François Mitterrand and Ronald Reagan are impressed by her strong international stature. She does not really cooperate with them; she rather tries to control them. In her "special relationship" with Ronald Reagan, she is sometimes presented as a devoted friend who would support him at all costs and, at other times, she yells at him to impose her own power. The so-called "special relationship" between the British and American leaders is caricatured to the extreme as they are once shown exchanging a long and passionate kiss, ${ }^{31}$ as if they were lovers. In real life, Thatcher and Reagan were close allies and friends as both advocated in favour of neoliberalism, monetarism as well as individualism and rejected communism. As far as François Mitterrand is concerned, he was reported to have said about her British counterpart that she had "the eyes of Caligula/Stalin and the mouth of Marilyn Monroe". ${ }^{32}$ This portrayal shows that she was an impressive figure able to ally stereotypes of masculinity with feminine clichés because she failed to conform to gender expectations.

In the first season, Margaret Thatcher meets a supposedly dead dictator : Adolf Hitler. ${ }^{33}$ The fact that Adolf Hitler lives next door to the 10 Downing Street residence enabled the makers of the TV show to draw a link between the Nazi Führer and the woman who came to be called "the Iron Lady" as if she were no more than a dictator or some sort of 
tyrant. In the show, when the two characters meet, they talk about contemporary British politics but the conversation is paved with misunderstandings as Hitler only makes references to the context of the Second World War. Therefore, when Margaret Thatcher means "SAS", "the Winter of Discontent" or "the [trade] unions", Hitler says "SS", highlights the importance of "not attacking in Winter" and mentions the "Soviet Union". On top of this series of misunderstandings which constitute an efficient basis for humour, Margaret Thatcher is tricked and ridiculed as, in spite of all the clues given by Hitler himself, she does not recognise the Nazi Führer and believes that his name is Jeremy von Wilcox, not a fugitive ex-dictator but a random German neighbour. Moreover, when Hitler tries to flirt with her, she does not notice his attempts. Hence she is presented as a person lacking common sense or, at least, deprived of any understanding of social conventions. This way of portraying her contrasts with her image of a politician managing the nation finances in a very pragmatic way. Besides, this precarious sociability points to her insensitivity which has been largely commented on by her political entourage as well as by the media. In a series of testimonies compiled by Iain Dale, she is for instance referred to as a "cold, unfeeling automaton". ${ }^{34}$ The producers of Spitting Image did not forget to build their caricature of Margaret Thatcher on that feature.

\section{From school mistress ${ }^{35}$ to sadistic dominatrix}

15 Almost every time Margaret Thatcher's media persona is having a meeting with her Cabinet colleagues, she is presented as an authoritarian school mistress humiliating them and punishing them. As far as her male colleagues are concerned, they behave like children who are particularly undisciplined and incompetent. Moreover, they are quite coward as they seem to fear their leader and never tell her what they think about her harsh methods. For example, in a short extract, the table around which the meeting takes place is full of papers and files and some of the members of the Cabinet are rocking on their chairs while others are crumpling papers. ${ }^{36}$ The mess in the Cabinet room seems to symbolise disorder in the Conservative Party at large. Margaret Thatcher thus takes all the decisions because her team is unable to work efficiently.

In another extract featuring a Cabinet meeting in the first season of the show, the Prime Minister interrogates her different ministers about political matters but all of them are spending their time playing with whatever they can find on the table and are fooling about. ${ }^{37}$ Margaret Thatcher's own game consists in humiliating them as if she were an excessively authoritarian teacher facing a bunch of childish pupils in a classroom. Therefore, we might claim that the different ministers are like puppets within the puppet show and Margaret Thatcher is like a deus ex machina directing them. Moreover, the ministers' cowardice relies on their inability to answer to the Prime Minister as they all seem to be highly scared of her. They all speak in a very soft way whereas she keeps on screaming and says that "the opposite of unanimous is fired". This apprehension towards Margaret Thatcher is very apparent in another extract where all the ministers hide their faces under the table whenever their leader starts yelling. ${ }^{38}$ Norman Tebbit, ${ }^{39}$ presented as her protégé, is used as a security guard who is allowed to hit his colleagues when they dare make awkward suggestions.

Steve Nallon, the actor who lipsynced Margaret Thatcher's puppet made her voice go from very strident tones - once, her husband's glasses smashed to pieces because of her 
shrill scream ${ }^{40}$ - to much deeper ones. The impression which emerges from these constant changes in voice pitch is one of an orator who could appear soft or tough according to the situations. Her colleagues, and the spectators, therefore never know when she is about to throw a tantrum.

Even US President Ronald Reagan is the victim of Margaret Thatcher's verbal assaults but he seems to like them in a quite masochistic way. ${ }^{41}$ The "special relationship" is thus presented as a relation between a dominant and a dominated partner, both of them agreeing to play their respective role. Interestingly, this representation corresponds to a reversal of the reality as the United States has always managed to put forward its superior status since the end of the Second World War.

The violence exuding from Margaret Thatcher's puppet is not only verbal as it sometimes turns into physical aggression. For instance, in season 3, there is a scene in which she hits one of her Cabinet ministers whom, in real life, Margaret Thatcher was often heard complaining about. ${ }^{42}$ This colleague, namely Geoffrey Howe, ${ }^{43}$ decided to resign in 1990 because of his disapproval with his leader's positions on Europe. Even though he was often caricatured as the harmless sheep of the Thatcher government, ${ }^{44}$ it is interesting to note that Howe's resignation eventually precipitated the Prime Minister's downfall. John Major, another of her colleagues who then succeeded her in her functions, is also presented as being her scapegoat. Besides, in the TV show, he is portrayed as someone who does everything he can for the sake of his leader. ${ }^{45}$ This depiction was elaborated on the basis of Major's public persona which was one of moderation and restraint. Margaret Thatcher's particularity as a woman surrounded by men on whom she imposed her sadistic attitude generated a representation full of sexual innuendos which easily attracted the spectators' attention, even if that attention was triggered by a sexist conception of social roles. Her cruelty towards men finds its apogee when she is shown waking up her husband Denis by pouring hot tea on his genitals. ${ }^{46}$ This attempt at emasculating her husband contrasts with Margaret Thatcher's declarations about preparing his breakfast in real life. ${ }^{47}$

The only extract in which Margaret Thatcher is dominated by someone else is when she is shown through the traits of Ronald Reagan's poodle and obeys his orders. ${ }^{48}$ This reversal of the roles is an exception which can be explained by the political context of the time : the US was asking Britain permission to use its airbases in order to attack Libya in 1986. Quite exceptionally, at that very moment, Britain was generally perceived as the subordinate partner in the "special relationship" whereas the US was seen as the dominant one.

21 The representation of Margaret Thatcher as a dominatrix is full of stereotypes and implies a focus on her hybrid sexual attitudes. Of course, she was a woman, but Spitting Image suggested that she behaved more like a man and sometimes even caricatured her as an inhuman creature.

\section{Woman, man or "alien" ?}

In the second season of the series, Margaret Thatcher's media persona started wearing a masculine outfit consisting in a suit and tie. As in real life, she still wore make up, jewellery and her famous handbag but her clothes were typically masculine. Her voice also evolved throughout the different seasons to become more authoritarian and deep, especially at the start of the third season. These changes in her voice more or less 
corresponded to those which took place in reality. In the show, in order to emphasize Margaret Thatcher's masculinity, her colleagues often call her "sir" instead of "madam" ${ }^{49}$ and she is shown at the urinals standing next to male colleagues like Michael Heseltine. $^{50}$

In the fourth season, another prop was added to Margaret Thatcher's puppet: she constantly appeared with a cigar in her hand. ${ }^{51}$ The fact that she wore a suit and tie and smoked cigars constituted a reference to one of her predecessors whom she admired, Winston Churchill. The real Margaret Thatcher mentioned Churchill in many of her speeches. For example, at a party conference, she declared :

You will understand, I know, the humility I feel at following in the footsteps of great men like [...] Winston Churchill, a man called by destiny who raised the name of Britain to supreme heights in the history of the free world..$^{52}$

Beyond denying Margaret Thatcher her femininity through the exaggeration of her male characteristics, Spitting Image sometimes deprived her of her humanity. In some sequences, she appeared as a frightening creature which was all but human. For example, there is a passage in which she is presented as the "perfect winning machine" able to win any election and where she is caricatured in the traits of a scary alien..$^{53}$ In this extract, a scientist analyses her DNA through a microscope and notices that "her DNA's structures are indestructible" and that "her defences are impenetrable". When Margaret Thatcher's media persona makes its entrance in the laboratory, it has the physical appearance of the alien from the Alien movies whose first instalment was released in 1979. Caricaturing the Prime Minister as a monster while highlighting her cruelty was commonplace at the time. In some tabloids, she also appeared as the big bad wolf or as Count Dracula. ${ }^{54}$

In another very short passage, we can see Margaret Thatcher using print stripper as a perfume..$^{55}$ Such a product should be toxic when applied to one's skin but it does not have any negative impact on Margaret Thatcher. This video extract thus constitutes a demonstration of her inhuman nature and contributed to her caricature as an outstanding personality.

\section{Conclusion}

26 As it is clearly stated in the TV show, the British Prime Minister had to endure " $a$ great deal of criticism and even personal abuse, some of it admittedly from Spitting Image". ${ }^{56}$ According to Kiene Brillenburg, the programme itself faced much criticism when it was launched because it was considered disrespectful towards politicians and the royal family. ${ }^{57}$ It was the return of "satire as an offensive practice" ${ }^{58}$ In an interview given in 2008, Peter Fluck confessed his aversion towards Margaret Thatcher and claimed that denouncing her evil sides had been one of the show's greatest achievements :

I still get a lot of people saying, "Thank you for helping me through the Thatcher years". People were losing their jobs, mines were being closed and Christ knows what was going on. People wanted a programme that was not afraid to tackle those issues. ${ }^{59}$

Some media organs, like the BBC, had adopted a quite anti-Thatcher stance as they were against the wholesale and radical changes she promoted through her encouragement of deregulation and competition. This new climate made the creation of innovative private media possible. Such was the case of Channel 4, launched in 1982. 
The popular press - essentially composed of tabloids like The Sun, The Daily Mail, The Express and News of the World ${ }^{60}$ - was dominated by an imposing figure and ally of Margaret Thatcher: Rupert Murdoch. Her good relationships with the media mogul made it easier for him to extend his empire. Indeed, as Jacques Leruez explains, tabloids were generally supportive of the Prime Minister as both Mr. Murdoch and Mrs. Thatcher helped each other acquire more power and influence in their respective domain. ${ }^{61}$

The puppets constituted a fictional intermediary enabling the producers of the show to express ideas which would probably have been more controversial had they been voiced by real actors. In this respect, there is a clear contrast with other programmes of the time such as Yes, Prime Minister or The New Statesman. That said, did Spitting Image succeed in expressing a clear political bias and in producing an efficient criticism of Margaret Thatcher's supremacy?

Although its viewership was exceptionally high in the 1980s, it is difficult to assess the TV show's real impact in terms of depreciation of the Prime Minister's image. Spitting Image probably fuelled criticism against the Conservatives and their leader which was one of its main objectives. Nevertheless, there is no clear correlation between enjoying the show for its political content and voting against the Conservative Party, personified by Margaret Thatcher, which happened to have much success in the polls throughout the 1980s. Spitting Image however reflected converging discourses from the trade unions, when it positioned itself in favour of Arthur Scargill ${ }^{62}$ in the context of the 1984-1985 miners' strike, but also from the Labour Party and left-wing intellectuals and artists who tended to criticise Margaret Thatcher for her lack of support for culture. The producers of the show continued to more or less indirectly support the Labour Party until 1996 when the programme stopped being broadcast. In that year, they even produced one of its campaign videos in which John Major was presented as an outgoing Prime Minister who had lost all of his credibility during his mandates. ${ }^{63}$

That said, Margaret Thatcher's portrayal as a strong personality who was, even if excessively, determined to follow her own track puts forward an image of political will and power. As power is generally seen as a political asset, it seems that the caricature elaborated by Spitting Image came to reinforce Margaret Thatcher's legitimacy and reputation. Moreover, Mrs. Thatcher was famous for being able to turn her flaws into positive qualities. For instance, when the Red Star, a Soviet newspaper, gave her the nickname "Iron Lady" in 1976 in order to blame her stubbornness, she immediately used it to her own advantage while redefining it in her own way:

I stand before you tonight in my Red Star chiffon evening gown, my face softly made up and my fair hair gently waved, the Iron Lady of the Western world. A Cold War warrior... Yes, I am an iron lady [...] ; yes, if that's how they wish to interpret my defence of values and freedoms fundamental to our way of life..$^{64}$

It seems that most of Margaret Thatcher's imperfections could easily be turned into positive attributes as all the satirical attacks against her participated in shaping her image as a fighter who would not allow herself to be destabilised by such criticism. Generally speaking, her main weapon was the attraction and fascination she prompted. Although she resigned in 1990 because of a loss of support from Conservative Members of Parliament, Spitting Image continued being broadcast and the new Prime Minister, John Major, was caricatured as a dull and uninteresting figure. ${ }^{65}$ 


$$
\begin{aligned}
& \text { and broadcast on ITV from } 6 \text { April to } 15 \text { June. Though it finally did not meet much } \\
& \text { success, it emerged from a necessity to disclose the backstage of British politics. As } \\
& \text { Henry Naylor declared on the day of the first broadcast : } \\
& \text { I think the need for a show like this is greater than ever. There is now a real spin } \\
& \text { culture in place and someone has to look behind that. Political figures now invite us } \\
& \text { into their homes and control almost every aspect of their public image. The viewer } \\
& \text { needs a way of getting back at that sort of behaviour. Our show will do that. }{ }^{66}
\end{aligned}
$$

2008, a new political puppet show called Headcases was produced by Henry Naylor

At a time when politicians make more and more often use of marketing strategies to display an attractive image to their potential electorate, a battle must be fought and political satire is needed as it can constitute a potent weapon for criticism. When this kind of satire does not succeed in enticing people to oppose political personalities, it can at least attract an audience that is not always interested in politics thanks to its comic dimension. If, like John Reith - founder of the BBC - we consider that the core mission of any media in a representative democracy is to first "inform", then "educate" and finally "entertain", we must admit that Spitting Image does constitute a harmonious combination of instruction and amusement.

\section{BIBLIOGRAPHY}

Baridon, Laurent and Guedron, Martial, L'Art et l'histoire de la caricature (Paris, Éditions Citadelles \& Mazenod, 2015 [2006]).

Blake, Stephen and John, Andrew, Iron Lady: The Thatcher Years (London, Michael O'Mara Books Limited, 2012 [2003]).

Brillenburg, Kiene, 'Spitting Image and Pre-Televisual Political Satire : Graphics and Puppets to Screens', Image and Narrative, vol. $12: 3$ (2011).

Brown, Mark, 'Spitting Image Creator Says Times Are Right for US Revival', The Guardian, 14 November 2018, <https://www.theguardian.com/tv-and-radio/2018/nov/14/spitting-imagecreator-says-times-are-right-for-us-revival> [9 May 2019].

Campbell, John, Margaret Thatcher. Volume One : The Grocer's Daughter (London, Jonathan Cape, 2000).

Cockerell, Michael, ‘The Making of the Iron Lady', BBC 4, 8 June 2008.

Dale, Iain (ed.), Memories of Margaret Thatcher : A Portrait, by Those Who Knew Her Best (London, Biteback Publishing Limited, 2013).

Fallon, Janet L., A Communication Perspective on Margaret Thatcher: Stateswoman of the Twentieth Century (New York, Lexington Books, 2017).

Hastings, Chris, 'Spitting Image Secrets Revealed by Creator', The Telegraph, 6 April 2008, <https:// www.telegraph.co.uk/news/uknews/1584109/Spitting-Image-secrets-revealed-by-creator.html> [7 May 2019].

Revue Française de Civilisation Britannique, XXIV-4 | 2019 
Kavanagh, Dennis and Seldon, Anthony, The Powers Behind the Prime Minister : The Hidden Influence of Number Ten (London, HarperCollins, 1999).

Leruez, Jacques, Le Système politique britannique : de Winston Churchill à Tony Blair (Paris, Armand Colin, 2001).

Leruez, Jacques, Thatcher : la dame de fer (Brussels, André Versaille Éditeur, 2012).

McNair, Brian, An Introduction to Political Communication (London, Routledge, 2011 [1995]).

Margaret Thatcher Foundation : <https://www.margaretthatcher.org> [14 May 2019].

Millat, Gilbert, 'Satire graphique et enracinement national : le dessin de presse britannique', Revue Française de Civilisation Britannique, XIII : 4 (1 January 2006, <http://

journals.openedition.org/rfcb/1647> [10 May 2019].

Moore, Charles, Margaret Thatcher, The Authorized Biography: Volume One (London, Penguin Books, 2014 [2013]).

Scammell, Margaret, 'Politics and Image : the Conceptual Value of Branding' in Smith, Gareth and Needham, Catherine (eds.), Journal of Political Marketing, vol. 14 : 1-2 (2015), pp. 7-18.

Shephard, Gillian, The Real Iron Lady: Working with Margaret Thatcher (London, Biteback Publishing Limited, 2013).

Thatcher, Margaret, The Downing Street Years (London, Harper Collins, 1993).

Thieriot, Jean-Louis, Margaret Thatcher (Paris, Éditions de Fallois, 2007).

\section{NOTES}

1. Laurent Baridon and Martial Guedron, L'Art et l'histoire de la caricature (Paris, Éditions Citadelles \& Mazenod, 2015 [2006]), p. 81.

2. Gilbert Millat, 'Satire graphique et enracinement national : le dessin de presse britannique', Revue Française de Civilisation Britannique, XIII: 4, 1 January 2006, http://journals.openedition.org/ rfcb/1647, consulted 10 May 2019.

3. Mark Brown, 'Spitting Image Creator Says Times Are Right for US Revival', The Guardian, 14 November 2018, https://www.theguardian.com/tv-and-radio/2018/nov/14/spitting-imagecreator-says-times-are-right-for-us-revival, consulted 9 May 2019.

4. As Margaret Scammell explains, a politician's image corresponds to his/her reputation: Margaret Scammell, 'Politics and Image: the Conceptual Value of Branding' in Gareth Smith and Catherine Needham (eds.), Journal of Political Marketing, vol.14 : 1-2, 2015, p. 5.

5. "Mme Thatcher ayant été le Premier ministre le plus important depuis Churchill et Attlee", Jacques Leruez, Thatcher: la dame de fer (Brussels, André Versaille Éditeur, 2012), p. 10.

6. "personnage", Ibid., p. 11.

7. Janet L. Fallon, A Communication Perspective on Margaret Thatcher: Stateswoman of the Twentieth Century (New York, Lexington Books, 2017), p. 15.

8. Laurent Baridon and Martial Guedron, L'Art et l'histoire de la caricature (Paris, Éditions Citadelles \& Mazenod, 2015 [2006]), p. 6.

9. Margaret Thatcher could count on the help of communication and media advisers like Tim Bell from the Saatchi and Saatchi agency, Gordon Reece or Bernard Ingham, in Dennis Kavanagh and Anthony Seldon, The Powers Behind the Prime Minister: The Hidden Influence of Number Ten (London, HarperCollins, 1999), p. 171. 
10. Brian McNair, An Introduction to Political Communication (London, Routledge, 2011 [1995]), pp. 10-11.

11. Kiene Brillenburg, 'Spitting Image and Pre-Televisual Political Satire: Graphics and Puppets to Screens', Image and Narrative, vol.12: 3, 2011, p. 114.

12. The use of the word "outsider" to describe Margaret Thatcher comes from Gillian Shephard, The Real Iron Lady: Working with Margaret Thatcher (London, Biteback Publishing Limited, 2013), p. 169. This expression has been studied by Karen Ross who considers it as one of the three frames used by the media to represent women politicians: Karen Ross, Gendered Media: Women, Men, and Identity Politics (Lanham, Rowman \& Littlefield, 2010).

13. Gillian Shephard, The Real Iron Lady: Working with Margaret Thatcher (London, Biteback Publishing Limited, 2013), pp. 169-170.

14. Margaret Thatcher, The Downing Street Years (London, Harper Collins, 1993), p. 24.

15. YouTube, https://www.youtube.com/watch?v=iOFvgiCyChA, consulted 3 August 2018.

16. The expression "media persona" is used as a synonym for "puppet". It enables the reader to make the difference between Margaret Thatcher as a real person and her parodic representation in Spitting Image.

17. The characterization of Margaret Thatcher as nothing more than a "grocer's daughter" was quite recurrent in the 1980s. For instance, the French President Valéry Giscard d'Estaing was said to have used this expression in a quite derogatory way.

18. YouTubehttps://www.youtube.com/watch?v=_rMnv6sZVow, 2'50" consulted 3 August 2018.

19. YouTube, https://www.youtube.com/watch?v=L2ZgwgHTBA8, 15'45", consulted 3 August 2018.

20. YouTube, https://www.youtube.com/watch?v=_rMnv6sZVow, 12'20", consulted 3 August 2018.

21. YouTube, https://www.youtube.com/watch?v=NlnvWCLbKYw, 17'35”, consulted 3 August 2018.

22. YouTube, https://www.youtube.com/watch?v=XH2XV-wC8vQ, 24'25", consulted 3 August 2018.

23. YouTube, https://www.youtube.com/watch?v=_rMnv6sZVow, 27'20", consulted 3 August 2018.

24. The Falklands War lasted from 2 April to 14 June 1982. It was triggered by Argentina's invasion of the Falkland Islands which were British territory. Margaret Thatcher responded by sending the British navy and finally defeated the Argentinian junta.

25. Margaret Thatcher authorized the United States to use Royal Air Force airbases in order to attack Libya. This decision caused much criticism against the British Prime Minister.

26. YouTube, https://www.youtube.com/watch?v=_rMnv6sZVow, 5'50", consulted 3 August 2018.

27. Nicholas Garland is a British caricaturist who worked for The Daily Telegraph from 1966 to 2011. Between 1986 and 1990, he interrupted his career at The Daily Telegraph to work for The Independent, created in 1986. In the 1970s, he had also worked for The New Statesman and The Spectator.

28. Nicholas Garland in Charles Moore, Margaret Thatcher, The Authorized Biography: Volume One (London, Penguin Books, 2014 [2013]), p. 640.

29. YouTube, https://www.youtube.com/watch?v=lrE8XfoY3ow, 0'00", consulted 3 August 2018.

30. Michael Foot was Leader of the Labour Party from 1980 to 1983.

31. YouTube, https://www.youtube.com/watch?v=_rMnv6sZVow, 30'00", consulted 3 August 2018.

32. There is uncertainty and debate about the exact words pronounced by François Mitterrand in a private meeting. According to most commentators, he compared Margaret Thatcher to Caligula while to his special adviser Jacques Attali, who was next to the French President when he pronounced those words, the comparison was not with the Roman Emperor but with Stalin. 
33. YouTube, https://www.youtube.com/watch?v=_rMnv6sZVow, 17'20", consulted 3 August 2018.

34. Iain Dale (ed.), Memories of Margaret Thatcher: A Portrait, by Those Who Knew Her Best (London, Biteback Publishing Limited, 2013), p. 173.

35. The use of the expression "school mistress" to portray Margaret Thatcher comes from Jacques Leruez, Thatcher: la dame de fer (Brussels, André Versaille Éditeur, 2012), p. 11: "maîtresse d'école".

36. YouTube, https://www.youtube.com/watch?v=_rMnv6sZVow, 2'30", consulted 3 August 2018.

37. YouTube, https://www.youtube.com/watch?v=jINZBOxdja8, consulted 3 August 2018.

38. YouTube, https://www.youtube.com/watch?v=_rMnv6sZVow, 4'15", consulted 3 August 2018.

39. Norman Tebbit was Margaret Thatcher's Secretary of State for Employment from 1981 to 1983 and her Secretary of State for Trade and Industry from 1983 to 1985. In 1985, he became Chairman of the Conservative Party.

40. YouTube, https://www.youtube.com/watch?v=_rMnv6sZVow, 13'40”, consulted 3 August 2018.

41. YouTube, https://www.youtube.com/watch?v=_rMnv6sZVow, 24'05”, consulted 4 August 2018.

42. YouTube, https://www.youtube.com/watch?v=RObqJFw-vpw, 3'55", consulted 4 August 2018.

43. Geoffrey Howe started working with Margaret Thatcher as Shadow Chancellor of the Exchequer from 1975 to 1979. In 1979, he became the government's Chancellor of the Exchequer and occupied other ministerial functions until he resigned in November 1990.

44. 'Geoffrey Howe: The Sheep That Roared', The Economist, 15 October 2015, https:// www.economist.com/britain/2015/10/15/the-sheep-that-roared, consulted 11 May 2019.

45. YouTube, https://www.youtube.com/watch?v=_rMnv6sZVow, 6'40", consulted 4 August 2018.

46. YouTube, https://www.youtube.com/watch?v=_rMnv6sZVow, 8'55", consulted 4 August 2018.

47. "I am a very ordinary person who leads a very normal life. I enjoy it - seeing that the family have a good breakfast." Daily Mirror, 3 February 1975, in John Campbell, Margaret Thatcher. Volume One: The Grocer's Daughter (London, Jonathan Cape, 2000), p. 296. "The welfare of her family is the prime concern of nearly every woman", 'Article on Women MPs (Youngest Woman Candidate Calls to Women)', Evening Post, $27^{\text {th }}$ January 1950, https://www.margaretthatcher.org/document/ 100855, consulted 11 May 2019.

48. YouTube, https://www.youtube.com/watch?v=_rMnv6sZVow, 9'30", consulted 4 August 2018.

49. YouTube, https://www.youtube.com/watch?v=kkb8FCZMn0w, 0'00", consulted 4 August 2018.

50. YouTube, https://www.youtube.com/watch?v=_rMnv6sZVow, 7'10", consulted 4 August 2018.

51. YouTube, https://www.youtube.com/watch?v=_rMnv6sZVow, 13'55", consulted 4 August 2018.

52. Margaret Thatcher's speech at the 1975 Conservative Party Conference, in Stephen Blake and Andrew John, Iron Lady: The Thatcher Years (London, Michael O'Mara Books Limited, 2012 [2003]), p. 141.

53. YouTube, https://www.youtube.com/watch?v=_rMnv6sZVow, 9'55", consulted 7 August 2018.

54. Jean-Louis Thieriot, Margaret Thatcher (Paris, Éditions de Fallois, 2007), p. 158.

55. YouTube, https://www.youtube.com/watch?v=_rMnv6sZVow, 21'45”, consulted 7 August 2018.

56. YouTube, https://www.youtube.com/watch?v=_rMnv6sZVow, 10'40”, consulted 7 August 2018.

57. Kiene Brillenburg, 'Spitting Image and Pre-Televisual Political Satire: Graphics and Puppets to Screens', Image and Narrative, vol.12: 3, 2011, p. 115.

58. Ibid., p. 116. 
59. Peter Fluck interviewed by journalist Chris Hastings, 'Spitting Image Secrets Revealed By Creator', The Telegraph, 6 April 2008, https://www.telegraph.co.uk/news/uknews/1584109/ Spitting-Image-secrets-revealed-by-creator.html, consulted 7 May 2019.

60. Jacques Leruez, Le Système politique britannique: de Winston Churchill à Tony Blair (Paris, Armand Colin, 2001), pp. 239-240.

61. Jacques Leruez, Thatcher: la dame de fer (Brussels, André Versaille Éditeur, 2012), pp. 132-133.

62. Arthur Scargill was the President of the National Union of Mineworkers from 1982 to 2002 . He was famous for leading the union during the 1984-1985 miners' strike and for being one of Margaret Thatcher's main adversaries during her time in power.

63. YouTube, https://www.youtube.com/watch?v=QBek3r1o1KI, consulted 15 May 2019.

64. Speech delivered by Margaret Thatcher in Finchley, 31 January 1976, in Charles Moore, Margaret Thatcher, The Authorized Biography: Volume One (London, Penguin Books, 2014 [2013]), p. 333.

65. 'Dominic West and the Greyness of John Major', The Telegraph, 30 September 2012, https:// www.telegraph.co.uk/news/politics/conservative/9574711/Dominic-West-and-the-greyness-ofJohn-Major.html, consulted 7 August 2018.

66. Henry Naylor interviewed by journalist Chris Hastings, The Telegraph, 6 April 2008, https:// www.telegraph.co.uk/news/uknews/1584109/Spitting-Image-secrets-revealed-by-creator.html, consulted 18 August 2018.

\section{ABSTRACTS}

The main ambition of this article is to pay tribute to Jacques Leruez whose work came to constitute a reference for British civilisation researchers focusing on the twentieth century. It provides a study of the representation of Margaret Thatcher's political image in the British television show called Spitting Image. This TV show was broadcast on ITV from 1984 to 1996. As that period included six years of her premiership, it is not surprising that Margaret Thatcher was one of the main characters in the show. Its aim was to offer a political caricature necessarily consisting in a distortion of reality. In the late twentieth century and, more precisely, in the 1980s, television developed as a means of communication throughout Western Europe thanks to the creation of new channels and the general deregulation of this market. As a consequence, it was increasingly used as a means of political propaganda or advertising whether by politicians themselves or by the media. One main ambition behind Spitting Image was to ridicule British politicians like Margaret Thatcher. Did the TV show succeed in building an efficient criticism thanks to its satirical dimension? This contribution will first highlight the different ways in which Margaret Thatcher was caricatured by Spitting Image. More precisely, it will focus on four different forms of representations which seemed to prevail in the show. As for the conclusion, it will be devoted to the ways in which her caricature was generally perceived by her fellow citizens.

Cet article a pour ambition première de rendre hommage à Jacques Leruez dont le travail vint à constituer une référence pour les chercheurs en civilisation britannique spécialistes du vingtième siècle. Il fournit une étude de la représentation de l'image politique de Margaret Thatcher dans l'émission télévisée britannique Spitting Image. Cette émission fut diffusée sur ITV de 1984 à 1996. Étant donné que la période incluait six années pendant lesquelles elle était 
Premier ministre, il n'y a rien d'étonnant à ce que Margaret Thatcher fût l'un des principaux protagonistes de l'émission. Son objectif était d'offrir une caricature politique qui consistait de fait en une distorsion du réel. Au cours de la seconde moitié du vingtième siècle et, plus précisément, dans les années 1980 , on assista à une propagation de la télévision en tant que moyen de communication à travers l'Europe de l'Ouest grâce à la création de nouvelles chaînes et à la dérégulation du secteur télévisuel. De ce fait, elle fut de plus en plus fréquemment utilisée par les personnalités politiques comme par les médias pour diffuser des propagandes électorales ou des publicités. Une des ambitions premières de Spitting Image était de railler les politiciens britanniques comme Margaret Thatcher. L'émission télévisée parvint-elle à constituer une critique efficace grâce à sa dimension satirique ? Cette contribution apportera tout d'abord un éclairage sur les différentes façons dont Margaret Thatcher fut caricaturée par Spitting Image. Elle mettra en évidence quatre formes de représentations qui semblaient primordiales. La conclusion, quant à elle, sera consacrée à la manière dont la caricature de Margaret Thatcher était perçue par ses concitoyens.

\section{INDEX}

Mots-clés: Thatcher, politique, médias, représentation, caricature, satire

Keywords: Thatcher, politics, media, representation, caricature, satire, Spitting Image

\section{AUTHOR}

\section{YVES GOLDER}

Equipe Savoirs dans l'Espace Anglophone : Représentations, Culture, Histoire,at the University of Strasbourg.

Yves Golder wrote and defended a PhD thesis on the construction of Margaret Thatcher's political image from 1950 to 1990 . His main interests are contemporary British civilisation, media communication and political sciences. Yves Golder is an English teacher at the faculty of law and political sciences of the University of Strasbourg as well as a member of the research team SEARCH EA2325. 